\title{
Interaction of Human Chorionic Gonadotropin (hCG) and Asialo-hCG with Recombinant Human Thyrotropin Receptor*
}

\author{
R. HOERMANN, M. BROECKER, M. GROSSMANN, K. MANN, AND M. DERWAHL \\ Medical Department II, Klinikum Grosshadern, University of Munich, D-81377 Munich; and the Clinic of \\ Internal Medicine, University of Bochum (M.B., M.D.), D-44789 Bochum, Germany
}

\begin{abstract}
hCG is a putative thyroid stimulator. The present studies were undertaken to examine its interaction and that of its desialylated variant asialo-hCG with recombinant human TSH (hTSH) receptor (hTSHr). To this end, we transfected a human thyroid carcinoma cell line (HTC) lacking endogenous TSHr with the full-length cDNA of the hTSHr. Unlike the wild type, the transfected cells, termed HTCTSHr cells, were able to bind bovine TSH (bTSH) with high affinity and increase cAMP production in response to bTSH stimulation. Of the hCG forms, intact hCG displayed a weak activity to inhibit $\left[{ }^{125} \mathrm{I}\right]$ bTSH binding to HTC-TSHr cells, with $100 \mathrm{mg} / \mathrm{L}\left(2.6 \times 10^{-6} \mathrm{~mol} / \mathrm{L}\right)$ producing maximally a $20 \%$ inhibition, whereas asialo-hCG achieved half-maximum binding inhibition at a concentration of $8 \mathrm{mg} / \mathrm{L}(2.3 \times$ $\left.10^{-7} \mathrm{~mol} / \mathrm{L}\right)$. The inhibitory constant $\left(\mathrm{K}_{\mathrm{i}}\right)$ of asialo-hCG for recombinant hTSHr was calculated from saturation experiments in the presence of variable doses of bTSH and a fixed concentration of asialohCG to be approximately $8 \times 10^{-8} \mathrm{~mol} / \mathrm{L}$. The interaction of asialohCG with TSHr was further assessed by studies of the direct binding
\end{abstract}

of the radioactively labeled hormone to both $\mathrm{HTC}$ and HTC-TSHr cells. $\left[{ }^{125} \mathrm{I}\right]$ Asialo-hCG binding to HTC-TSHr cells was $4.7 \%$, compared to $1.5 \%$ in the wild-type cells lacking $\mathrm{TSHr}$ and was displaceable by bTSH (0.1-100 IU/L), indicating specific binding of the tracer to TSHr. Functionally, hCG (up to $100 \mathrm{mg} / \mathrm{L} ; 2.6 \times 10^{-6} \mathrm{~mol} / \mathrm{L}$ ) proved unable to evoke any significant cAMP response over basal values in HTCTSHr cells, as did asialo-hCG. Asialo-hCG, but not hCG, inhibited bTSH-stimulated adenylate cyclase activity in the cells in a dosedependent manner.

In conclusion, the present data show that intact $\mathrm{hCG}$ binds only weakly to HTC-TSHr cells and produces no significant cAMP stimulation, which is at variance with data obtained in FRTL-5 and Chinese hamster ovary-TSHr cells, but in good accord with previous findings in human thyroid membranes. Asialo-hCG, on the other hand, strongly binds to recombinant TSHr and inhibits the cAMP response to bTSH in HTC-TSHr cells, indicating that the desialylated hCG variant directly interacts with the receptor and truly is an antagonist of the hTSHr. ( $J$ Clin Endocrinol Metab 78: 933-938, 1994)
$\mathrm{W}^{\mathrm{s}}$ E AND others have previously reported that hCG displayed a weak activity to inhibit the binding of $\left[{ }^{125} \mathrm{I}\right]$ bovine TSH ([125 I]bTSH) to human thyroid membranes, but was unable to produce any significant stimulation of the cAMP response in such membrane preparations $(1,2)$. In other systems using thyroid tissue or cells of nonhuman origin, on the other hand, hCG has readily been identified as a thyroid stimulator of considerable potency (3-5). The failure to demonstrate a thyrotropic activity of hCG in human thyroid preparations in vitro may be due to species variations in the thyroid response to $\mathrm{hCG}$ or to a lack of sensitivity of the assay systems used. The affinity of hCG for TSH receptor (TSHr) can be enhanced by desialylation of the molecule, which transforms the hormone into a more potent agonist in FRTL-5 thyroid cells and a strong TSH antagonist in human thyroid membranes (6-9).

Following the successful cloning of the human TSH (hTSH) receptor, it became possible to study both the direct

Received September 9, 1993. Accepted December 8, 1993.

Address all correspondence and requests for reprints to: Dr. Rudolf Hoermann, Medical Department II, Klinikum Grosshadern, University of Munich, Marchioninistrasse 15, D-81377 Munich, Germany.

* A portion of these findings was presented in abstract form at the 37th Annual Meeting of the German Endocrine Society. Berlin, Germany (Exp Clin Endocrinol [Suppl 1] 101:154, 1993) and the 67th Annual Meeting of the American Thyroid Association, Tampa, FL, 1993 (Abstract T-84). This work was supported in part by a grant (De 407/2-2) from the Deutsche Forschungsgemeinschaft, Bonn, Germany (to M.D.). interaction of hCG with recombinant hTSHr and its functional consequences with respect to cAMP response $(10,11)$. In fact, Tomer et al. (12) recently reported that Chinese hamster ovary $(\mathrm{CHO})$ cells transfected with hTSHr were stimulated by hCG to release CAMP.

In view of the discrepant results that have been reported in human thyroid membranes and a recombinant $\mathrm{hTSHr}$ system, we undertonk the present studies to examine the direct interaction of hCG and its desialylated variant form with recombinant hTSHr. To this end, we assessed their abilities to both inhibit $\left[{ }^{125} \mathrm{I}\right] \mathrm{bTSH}$ binding to a human thyroid carcinoma cell line (HTC) that lacked endogenous TSHr, but expressed the recombinant $\mathrm{hTSHr}$, and to influence basal as well as bTSH-stimulated cAMP production in the cells.

\section{Materials and Methods}

\section{Materials}

Labeled bTSH was kindly provided by Dr. V. Herzog (University of Bonn, Bonn, Germany) and the unlabeled hormone $(\sim 30 \mathrm{IU} / \mathrm{mg})$ was purchased from Sigma (Deisenhofen, Germany). Crude urinary hCG ( $\sim 2500 \mathrm{IU} / \mathrm{mg}$ ) was obtained from Ayerst (Rouses Point, NY).

For desialylation of hCG, immobilized neuraminidase from Clostridium perfringens (type VI-A) was used (Sigma Chemical Co.). Cell culture reagents were purchased from Gibco-BRL (Eggenstein, Germany), ${ }^{125} \mathrm{I}$ from Behring (Marburg, Germany), and cAMP RIA kits from New England Nuclear-DuPont (Bad Homburg, Germany).

The human thyroid cell line HTC derived from a follicular carcinoma 
was kindly provided by Dr. Goretzki (University of Duesseldorf, Duesseldorf, Germany) (13). hTSHr cDNA and the eukaryotic expression plasmid pSV2-NEO-ECE employed for transfection of HTC cells were generous gifts from Dr. B. Rapoport (University of California-San Francisco) (11).

\section{Preparation of $h C G$ and asialo- $h C G$}

Highly purified hCG $(\sim 12,000 \mathrm{IU} / \mathrm{mg})$ was isolated from crude $\mathrm{hCG}$ by sequential chromatography on columns of DEAE-52 and Sephadex G-100, as described previously, and was immunologically and biologically indistinguishable from hCG CR 123 (NIH) (2). To obtain asialo$\mathrm{hCG}$, purified hCG was desialylated by digestion with neuraminidase following the protocol of van Hall et al. (14), which has been previously employed in our laboratory $(2,6,9)$. Desialylation was more than $80 \%$ complete, as assessed by measuring sialic acid concentrations according to the colorimetric method of Warren (15) before and after the incubation with neuraminidase.

\section{Transfection of HTC cells}

hTSHr cDNA, inserted into EcoRI sites of the eukaryotic expression plasmid pSV2-NEO-ECE, was transfected into the human thyroid carcinoma cell line HTC, which lacks endogenous TSHr, by the use of a modified lipofection method, as described previously (16-18). After selection of transfected cells by adding $400 \mathrm{mg} / \mathrm{L}$ Geneticin (GIBCO, Grand Island, NY) to the culture medium, a limiting dilution was performed to isolate distinct clones. Cells transfected with the plasmid without hTSHr cDNA served as negative controls.

\section{Cell cultures}

The transfected cells, termed HTC-TSHr cells, as well as the controls were routinely grown in $75-\mathrm{cm}^{2}$ culture flasks in Coon's modified Ham's F-12 medium, supplemented with $10 \%$ fetal calf serum and five hormones or growth factors $(10 \mu \mathrm{g} / \mathrm{L}$ glycyl-histidyl-lysine, $10 \mathrm{mg} / \mathrm{L}$ insulin, $10 \mu \mathrm{g} / \mathrm{L}$ somatostatin, $5 \mathrm{mg} / \mathrm{L}$ transferrin, and $3.2 \mu \mathrm{g} / \mathrm{L}$ hydrocortisone) $(17,18)$. The cells were cultured in humidified $5 \% \mathrm{CO}_{2}-95 \%$ air, fed three times weekly, and passaged every 10 days.

\section{Radiolabeled ligand binding}

hCG was labeled with ${ }^{125}$ I using a stoichiometric chloramine- $\mathrm{T}$ technique and desialylated to obtain asialo-hCG tracer, as described previously $(2,6,9)$. To study radiolabeled ligand binding, cells were transferred into 24 -well plates ( $\sim 10^{4}$ cells/well). Incubation was conducted in the presence of approximately $8000 \mathrm{cpm}\left[{ }^{125} \mathrm{I}\right] \mathrm{bTSH}(\mathrm{SA}, 40-60 \mathrm{mCi} /$ $\mathrm{mg})$ or $\left[{ }^{125} \mathrm{I}\right]$ asialo-hCG $(30-40 \mathrm{mCi} / \mathrm{mg})$ for $2 \mathrm{~h}$ at $37 \mathrm{C}$ in Hanks' Modified Buffer without $\mathrm{NaCl}$, containing $0.25 \% \mathrm{BSA}$ and $280 \mathrm{mmol} / \mathrm{L}$ sucrose $(6,17,18)$. For inhibition experiments, the indicated amounts of unlabeled bTSH, hCG, and asialo-hCG, respectively, were added together with the tracer. In addition, the saturation kinetics of bTSH binding were studied in the absence and presence of fixed concentrations of the putative inhibitors hCG or asialo-hCG. At the end of the incubation period, cells were rinsed and solubilized with $1 \mathrm{~mL} 1 \mathrm{~N} \mathrm{NaOH}$, and radioactivity was determined in a $\gamma$-counter. Nonspecific binding was measured in the presence of excess unlabeled ligand $(10,000 \mathrm{IU} / \mathrm{L}$ $\mathrm{bTSH}$ ) and subtracted to yield specific binding values. In addition to the bound/total $(B / T)$ representation, data were analyzed by Scatchard plotting and computer-aided curve fitting with the Ligand program (19, $20)$.

\section{Determination of cellular cAMP production}

Cells maintained in medium devoid of b1SH (H5 medium) for 5 days were incubated for $30 \mathrm{~min}$ at $37 \mathrm{C}$ with $1 \mathrm{mmol} / \mathrm{L} \mathrm{1-methyl-3-isobu-}$ tylxanthine in the presence of various concentrations of bTSH, hCG, asialo-hCG, or a combination of bTSH and the hCG forms. After solubilization of the cells with ethanol, the intracellular cAMP concentration was measured by a commercially available RIA, according to the manufacturer's guidelines, and related to the protein content of the cells $(17,18)$.

\section{Statistical methods}

For statistical comparison of data, Wilcoxon's test for unpaired observations was used.

\section{Results}

\section{Binding studies to HTC and HTC-TSHr cells}

HTC cells derived from a human thyroid follicular carcinoma apparently lacked the ability to express TSHr on their surface, as evidenced by specific $\left[{ }^{125} \mathrm{I}\right] \mathrm{bTSH}$ binding ranging from $0.3-1.3 \%$. After transfection of the cells with hTSHr CDNA, specific [ $\left.{ }^{125} \mathrm{I}\right] \mathrm{bTSH}$ binding markedly increased, exceeding $6 \%$ in all experiments conducted. Nonspecific binding was approximately $1 \%$ in both HTC and HTC-TSHr cells. Unlabeled bTSH inhibited tracer bound to HTC-TSHr cells in a dose-dependent manner, requiring a concentration of approximately $1 \mathrm{IU} / \mathrm{L}\left(1.2 \times 10^{-9} \mathrm{~mol} / \mathrm{L}\right)$ for half-maximum binding inhibition (Fig. 1). Of the hCG forms, intact $\mathrm{hCG}$ displayed little activity to inhibit $\left[{ }^{125} \mathrm{I}\right] \mathrm{bTSH}$ binding, with $100 \mathrm{mg} / \mathrm{L}\left(2.6 \times 10^{-6} \mathrm{~mol} / \mathrm{L}\right)$ effecting only approximately $20 \%$ inhibition. Asialo-hCC, on the other hand, proved much more potent in this respect, with only $8 \mathrm{mg} / \mathrm{L}(2.3 \times$ $10^{-7} \mathrm{~mol} / \mathrm{L}$ ) being required for half-maximum inhibition of $\left[{ }^{125} \mathrm{I}\right] \mathrm{bTSH}$ binding and $100 \mathrm{mg} / \mathrm{L}\left(2.9 \times 10^{-6} \mathrm{~mol} / \mathrm{L}\right)$ producing nearly complete binding inhibition (Fig. 1). AsialohCG, when compared on the basis of molar concentrations effecting half-maximum inhibition of $\left[{ }^{125} \mathrm{I}\right] \mathrm{bTSH}$ binding $\left(\mathrm{ID}_{50}\right)$, was calculated to be approximately $0.5 \%$ as potent as bTSH. Intact hCG could not be compared in this respect, because half-maximum binding inhibition of the tracer was

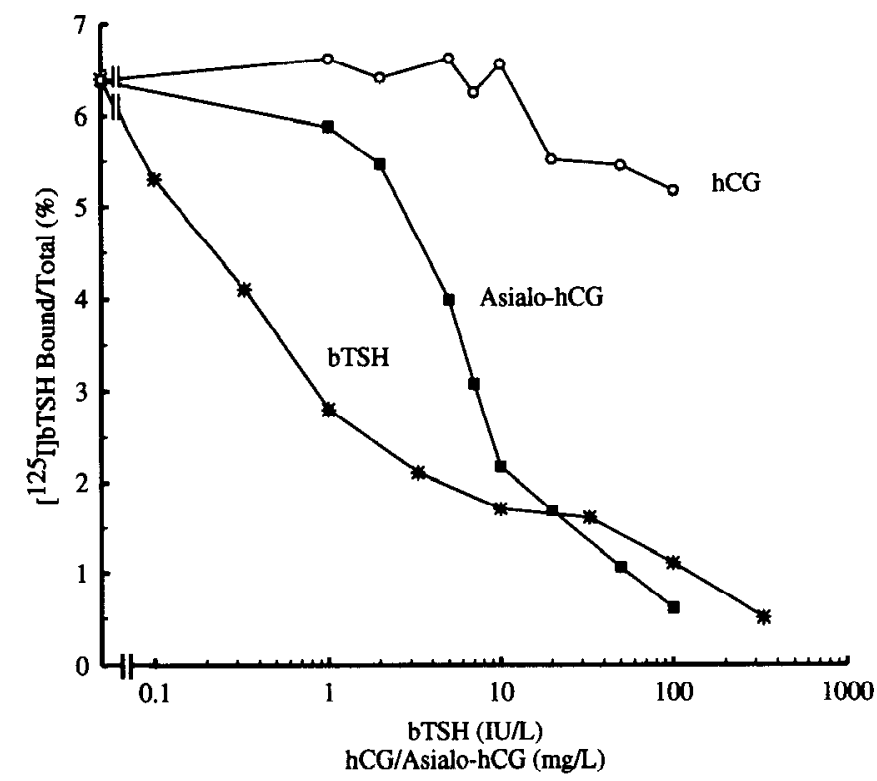

FIG. 1. Inhibition of the specific binding of $\left[{ }^{125} \mathrm{I}\right] \mathrm{bTSH}$ to HTC-TSHr cells by bTSH, hCG, and asialo-hCG. Incubations were carried out for $2 \mathrm{~h}$ at $37 \mathrm{C}$ in Hanks' Modified Buffer, as described in Materials and Methods. Each value represents the mean of closely concurring quadruplicate determinations. 
not achieved with the highest dose used (Fig. 1).

To further elucidate the mechanism of bTSH binding inhibition by the hCG forms, experiments were conducted to study the saturation kinetics of bTSH binding in the absence and presence of the inhibitor (Fig. 2). As indicated by Scatchard plotting and computer-assisted curve fitting of the data obtained with bTSH alone, two apparent binding sites for bTSH were present in HTC-TSHr cells, one of high affinity $\left(\sim 7 \times 10^{-10} \mathrm{~mol} / \mathrm{L}\right)$ and relatively low capacity $\left(B_{\max }\right.$ $3 \times 10^{-12} \mathrm{~mol} / \mathrm{L} ; \sim 1 \mathrm{fmol} / 10,000$ cells) and the other of lower affinity $\left(\sim 1 \times 10^{-7} \mathrm{~mol} / \mathrm{L}\right)$ and higher capacity $\left(B_{\max }\right.$ $9 \times 10^{-10} \mathrm{~mol} / \mathrm{L} ; \sim 300 \mathrm{fmol} / 10,000$ cells). The wild-type cells, on the other hand, exhibited only the low affinity TSHbinding sites, which are apparently unrelated to TSHr. Analysis of bTSH binding to HTC-TSHr cells in the presence of fixed concentrations $\left(2\right.$ and $4 \mathrm{mg} / \mathrm{L} ; \sim 0.5$ and $1 \times 10^{-7}$ $\mathrm{mol} / \mathrm{L}$ ) of $\mathrm{hCG}$ or asialo-hCG revealed the former to be inactive, but the latter to be a competitive inhibitor at the high affinity sites (Fig. 2). In another experiment, similar to the one depicted in Fig. 2, the concentration of hCG was increased to $66 \mathrm{mg} / \mathrm{L}\left(1.7 \times 10^{-6} \mathrm{~mol} / \mathrm{L}\right)$, which resulted in no significant change in the curve compared to the bTSH curve alone, and that of asialo-hCG to $8 \mathrm{mg} / \mathrm{L}\left(2.3 \times 10^{-7}\right.$ $\mathrm{mol} / \mathrm{L}$ ), which resulted in a nearly complete ablation of high affinity bTSH binding. The calculated $\mathrm{K}_{\mathrm{i}}$ of asialo-hCG for recombinant TSHr was approximately $8 \times 10^{-8} \mathrm{~mol} / \mathrm{L}$.

To further corroborate a direct interaction of asialo-hCG with recombinant TSHr, we performed direct binding studies with the radioactively labeled hormone to HTC and HTC-

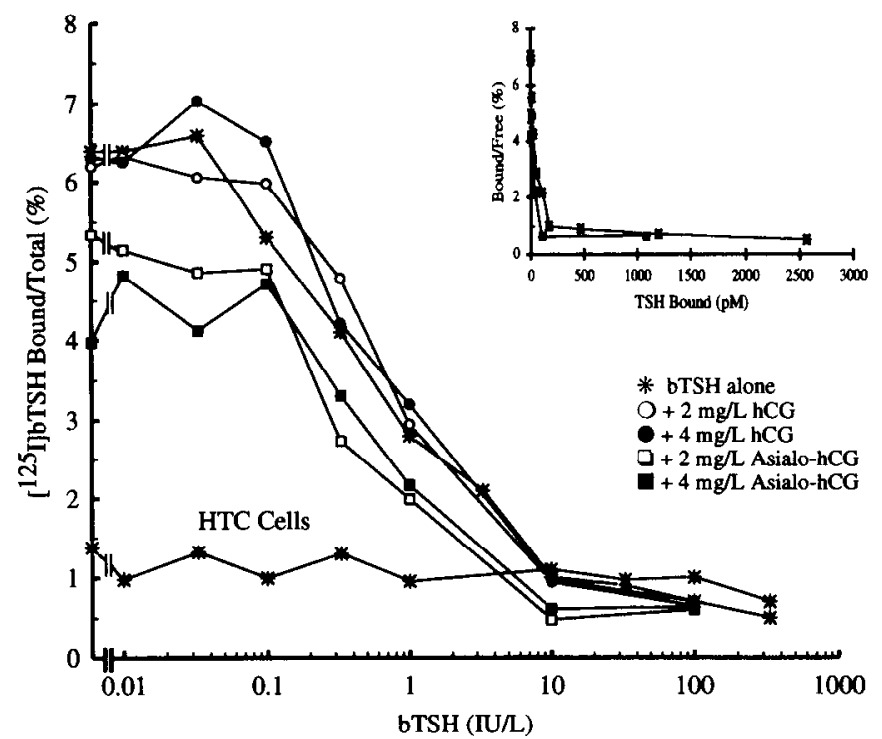

FIG. 2. Specific binding of $\left[{ }^{125} \mathrm{I}\right] \mathrm{bTSH}$ to HTC-TSHr cells at variable doses of cold bTSH in the presence and absence of fixed concentrations of $\mathrm{hCG}$ or asialo-hCG. The incubation conditions were the same as those described in Fig.1. The inset shows the Scatchard plots of bTSH binding alone and bTSH binding in the presence of $4 \mathrm{mg} / \mathrm{L}$ asialohCG. The results indicate the presence of two apparent binding sites for bTSH $\left(\mathrm{K}_{\mathrm{d} 1}, 7.1 \times 10^{-10} \mathrm{~mol} / \mathrm{L} ; \mathrm{K}_{\mathrm{d} 2}, 1.1 \times 10^{-7} \mathrm{~mol} / \mathrm{L} ; \mathrm{B}_{\max 1}, 3 \times\right.$ $10^{-12} \mathrm{~mol} / \mathrm{L}$ or $1 \mathrm{fmol} / 10,000$ cells; $B_{\max 2}, 9 \times 10^{-10} \mathrm{~mol} / \mathrm{L}$ or $300 \mathrm{fmol} /$ 10,000 cells) and a competitive inhibition of asialo-hCG at the high affinity binding sites in HTC-TSHr cells. For comparison, the wildtype cells (HTC cells) exhibited only the low affinity bTSH-binding sites.
TSHr cells. Specific binding of $\left[{ }^{125} \mathrm{I}\right] \mathrm{asialo}-\mathrm{hCG}$ was $4.7 \%$ to the transfected cells compared to $1.5 \%$ to the wild-type cells $(P<0.001$, by Wilcoxon's test; $n=4)$, and this binding could be inhibited in a dose-related manner by bTSH, indicating direct binding of the asialo-hCG tracer to TSHr (Fig. 3).

\section{cAMP production in HTC and HTC-TSHr cells}

bTSH stimulated intracellular cAMP production in HTCTSHr cells in a dose-dependent fashion, and $10 \mathrm{IU} / \mathrm{L} \mathrm{bTSH}$ increased basal cAMP levels approximately 9-fold (Fig. 4). A significant increase over basal values was observed at doses ranging between $0.05-0.1 \mathrm{IU} / \mathrm{L} \mathrm{bTSH}$, and half-maximum stimulation occurred at approximately $0.2-0.5 \mathrm{IU} / \mathrm{L}$ bTSH. In control cells, as expected from their negligible specific binding of $\left[{ }^{125} \mathrm{I}\right] \mathrm{bTSH}$, cAMP production could not be significantly augmented by bTSH in concentrations up to $100 \mathrm{IU} /$ $\mathrm{L}$ (data not shown). Unlike bTSH, both hCG and asialohCG, when added to the transfected cells in concentrations up to $100 \mathrm{mg} / \mathrm{L}\left(2.6\right.$ and $2.9 \times 10^{-6} \mathrm{~mol} / \mathrm{L}$, respectively), were ineffective in significantly increasing basal cAMP production (Fig. 4). This was also true for the control cells (data not shown).

Next, we examined the effect of hCG and its desialylated variant on bTSH-stimulated cAMP production in $\mathrm{HTC}-\mathrm{TSHr}$ cells. In the presence of bTSH alone $(0.5 \mathrm{IU} / \mathrm{L})$, cAMP production was stimulated approximately 5 -fold. Although the addition of intact hCG (up to $400 \mathrm{mg} / \mathrm{L} ; 1.1 \times 10^{-5} \mathrm{~mol} /$ L) did not significantly affect the cAMP response to bTSH, asialo-hCG, added in increasing concentrations from $10 \mathrm{mg} /$ $\mathrm{L}\left(2.9 \times 10^{7} \mathrm{~mol} / \mathrm{L}\right)$ to $200 \mathrm{mg} / \mathrm{L}\left(5.7 \times 10^{-6} \mathrm{~mol} / \mathrm{L}\right)$, showed a dose-dependent inhibition of bTSH-stimulated cAMP production (Fig. 5). The highest dose of asialo-hCG tested, 200 $\mathrm{mg} / \mathrm{L}\left(5.7 \times 10^{-6} \mathrm{~mol} / \mathrm{L}\right)$, was able to diminish by $90 \%$ the cAMP stimulation produced by $0.5 \mathrm{IU} / \mathrm{L} \mathrm{bTSH}$. When increasing the stimulatory bTSH concentration from 0.5 to 1 $\mathrm{IU} / \mathrm{L}$, the inhibitory effect of asialo-hCG was observed to

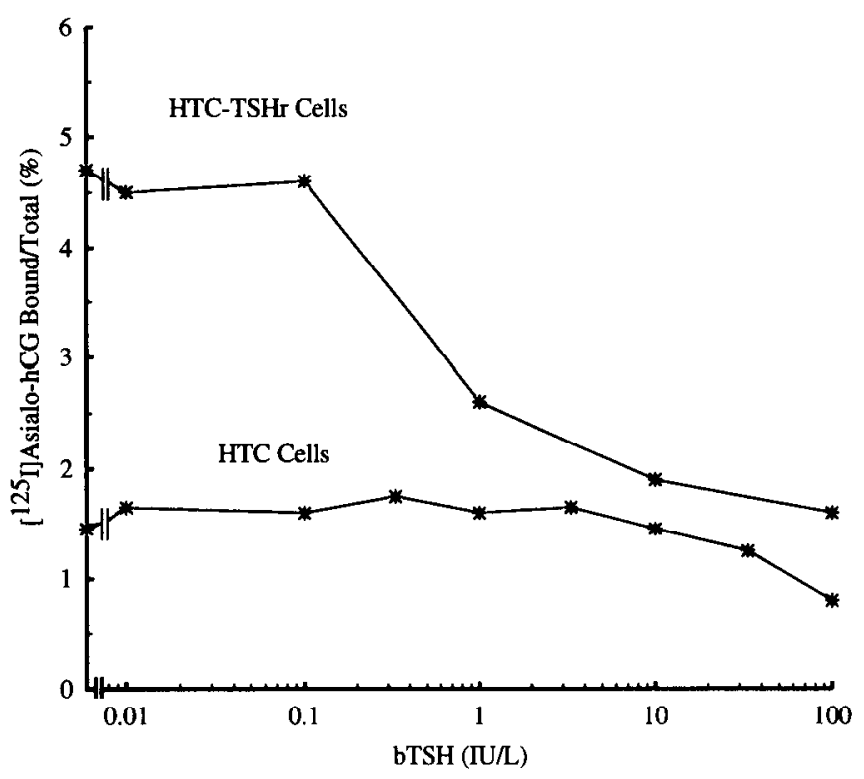

FIG. 3. Specific binding of $\left[{ }^{125} \mathrm{I}\right]$ asialo-hCG to H'TC and H'CC-TSHr cells and its displacement by bTSH. 


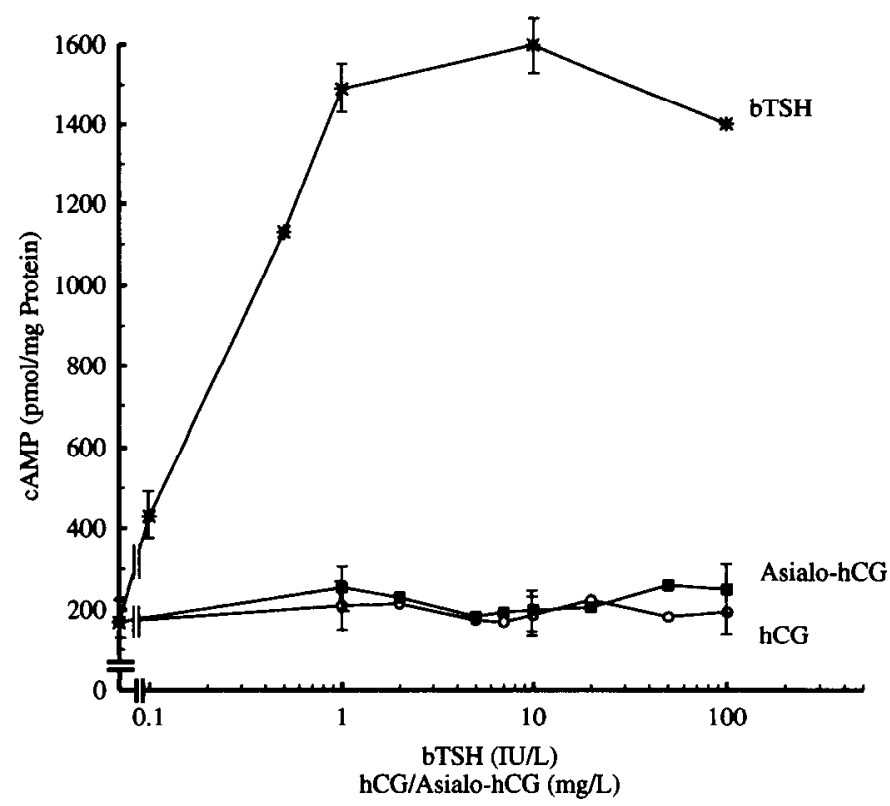

FIG. 4. Stimulation of cAMP production in HTC-TSHr cells. After maintenance in $\mathrm{H} 5$ medium for 5 days, cells transfected with the hTSHr were incubated in the presence of $1 \mathrm{mmol} / \mathrm{L} 1$-methyl-3-isobutylxanthine with the indicated concentrations of bTSH, hCG, and asialohCG, respectively. Vertical bars indicate the mean \pm SD of quadruplicate determinations; the other points represent the means of closely concurring duplicate determinations.

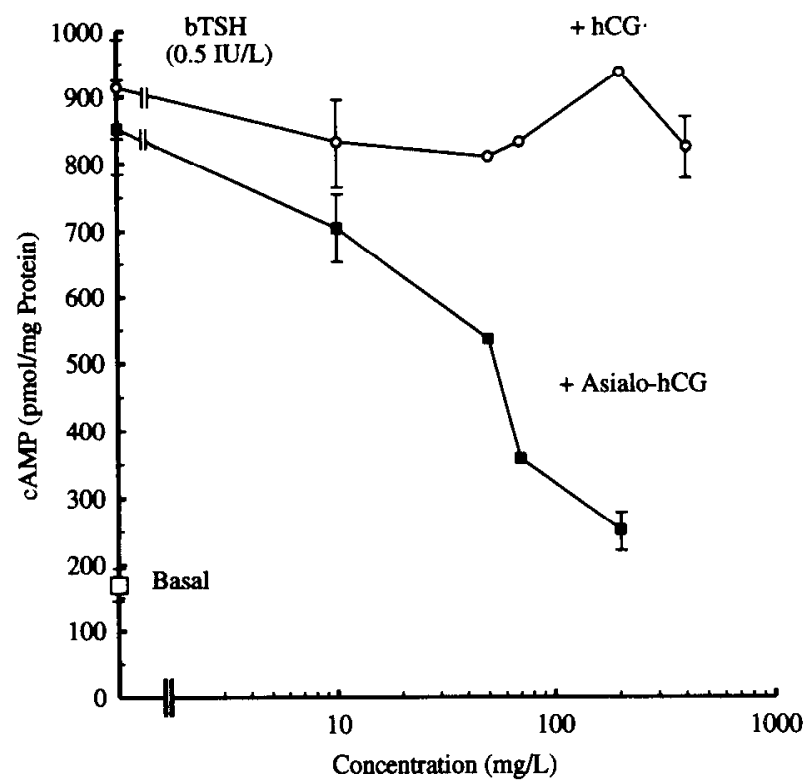

FIG. 5. Effects of hCG and asialo-hCG on bTSH-stimulated cAMP production in HTC-TSHr cells. An approximately half-maximum stimulatory dose of bTSH $(0.5 \mathrm{IU} / \mathrm{L})$ was used in this experiment, and bTSH alone produced an approximately 5 -fold stimulation of cAMP production, which was inhihited by the addition of asialo-hCG, but not hCG. Vertical bars indicate the mean \pm SD of quadruplicate determinations; the other points represent the means of closely concurring duplicate determinations.

decrease ( $40 \%$ inhibition at $\left.200 \mathrm{mg} / \mathrm{L} ; 5.7 \times 10^{-6} \mathrm{~mol} / \mathrm{L}\right)$, indicating a competitive mode of action of the inhibitor.

\section{Discussion}

Interest in studies of the thyrotropic activity of hCG originates from its putative roles as the thyroid stimulator responsible for thyroid hyperfunction associated with trophoblastic tumors and a regulator of maternal thyroid function during normal pregnancy (21-29). The question of whether $\mathrm{hCG}$ is indeed a thyroid stimulator of significant potency in man is, however, still discussed controversially, and evidence both in favor and against this view has been reported (3035 ). In the present studies we have undertaken to investigate the interaction of hCG with recombinant hTSHr, exploring its ability to both inhibit the binding of $\left[{ }^{125} \mathrm{I}\right] \mathrm{bTSH}$ to the recombinant receptors and enhance cAMP production in cells expressing the recombinant receptors. To mimic human physiology as closely as possible, cloned hTSHr cDNA was transfected to and expressed in a human thyroid carcinoma cell line (HTC) that lacked endogenous TSHr, rather than in other systems, such as $\mathrm{CHO}$ cells. The HTC cells and its properties after transfection with the hTSHr cDNA have been described and characterized previously by our group and others $(13,17,18)$. Particularly, HTC-TSHr cells have recently been demonstrated to retain the ability to synthesize thyroglobulin mRNA, which ascertains their descent from thyroid epithelium cells, and to express a functional TSHr coupled to the $G_{s}$ protein-adenylate cyclase complex, which is absent in the wild type (17).

Purified hCG when incubated in increasing concentrations with $\left[{ }^{125} \mathrm{I}\right] \mathrm{bTSH}$ or added in a fixed concentration together with variable doses of cold bTSH displayed a weak activity to inhibit bTSH binding to HTC-TSHr cells, with $100 \mathrm{mg} / \mathrm{L}$ $\left(2.6 \times 10^{-6} \mathrm{~mol} / \mathrm{L}\right)$ producing maximally a $20 \%$ inhibition. As for its functional effect, hCG in concentrations up to 100 $\mathrm{mg} / \mathrm{L}\left(2.6 \times 10^{-6} \mathrm{~mol} / \mathrm{L}\right)$ proved unable to evoke any significant cAMP response over basal values in the cells, nor was it a meaningful inhibitor of bTSH-stimulated adenylate cyclase activity. The absence of a functional response despite demonstration of weak TSH binding inhibiting activity may be explained by different dose requirements for the two effects or, more likely, occupancy by hCG of low affinity TSH-binding sites, which has been reported to be unrelated to TSHr and unaccompanied by a cAMP effect (36-38). These findings are entirely consistent with the data that have previously been reported using human thyroid membranes $(1,2)$. They are, however, at variance with our own data and the findings of others that have been obtained in FRTL-5 and CHO-TSHr cells $(4-6,12,39)$. Tomer et al. (12) and Yoshimura and co-workers (39), who studied expression of the hTSHr cDNA in CHO cells, showed a dose-related cAMP stimulation in response to purified hCG. With $9.6 \times 10^{-7}$ $\mathrm{mol} / \mathrm{L}$ hCG causing a definitive increase in cAMP and 100 IU hCG producing a cAMP stimulation equivalent to $9.2 \mu \mathrm{U}$ recombinant $\mathrm{hTSH}$, as reported by these researchers, the thyroid-stimulating potency of hCG in CHO-TSHr cells resembled that previously calculated using FRTL-5 thyroid cells, but exceeded by far the thyrotropic activity of hCG displayed in human thyroid membranes $(1,4,6,12,26,39)$. Data regarding the binding of hCG to recombinant TSHr or the $\mathrm{CHO}$ cells themselves were not shown in these reports 
$(12,39)$.

The striking discrepancies in the thyrotropic activity of hCG depending on the assay system used are difficult to explain. Species variation in the thyroid response to $\mathrm{hCG}$, similar to that observed with other thyroid stimulators, such as Graves' immunoglobulins (40), could be one possible explanation, as has been suggested by some researchers (3). Further, FRTL-5 and CHO-TSHr cells appear to be generally more sensitive to stimulation by TSH than the HTC-TSHr cells used in the present work (4-6, 11, 12, 17, 39). In this respect, bTSH evoked a significant response in concentrations of 12.3-37 mIU/L in the CHO-TSHr cells used by Yoshimura et al. (39) compared to 50-100 mIU/L required in HTC-TSHr cells. However, even among $\mathrm{CHO}$ cell clones expressing the recombinant hTSHr, TSH sensitivity has been reported to vary widely (41). Apart from the fact that different TSH preparations and conditions were used for stimulation of these cells, the main difference between the cell lines expressing recombinant hTSHr is the number of receptors per cell. Whereas Rapoport's (36) CHO-TSHr cells express approximately $10^{5} \mathrm{TSHr} /$ cell, $\mathrm{CHO}-\mathrm{TSHr}$ cells transfected by the group of Vassart $(41,42)$ express between 2,000 (clone JP 26) and 90,000 (clone JP 09) receptors per cell. The HTCTSHr cells used in the present studies express approximately 2,300 receptors/cells, which is in the same range as that of human thyroid cells $(17,43)$. Thus, it is conceivable that the stimulatory effect of hCG on cAMP generation in $\mathrm{CHO}$ TSHr cells may be at least in part due to a supraphysiological number of TSHr expressed by these cells $(12,39)$.

Desialylation of the hCG molecule resulted in a marked increase in the affinity of the hormone to recombinant $\mathrm{hTSHr}$, and asialo-hCG achieved a half-maximum inhibition of $\left[{ }^{125} \mathrm{I}\right] \mathrm{bTSH}$ tracer binding at a concentration of $8 \mathrm{mg} / \mathrm{L}$. Its inhibitory constant $\left(\mathrm{K}_{\mathrm{i}}\right)$ was calculated to be approximately 8 $\times 10^{-8} \mathrm{~mol} / \mathrm{L}$ on the basis of analysis of saturation kinetics in the presence of variable doses of TSH and a fixed concentration of asialo-hCG. Furthermore, radioactively labeled asialo-hCG was shown to specifically bind to recombinant hTSHr, and this binding was displaceable by bTSH. Although desialylated hCG has long been known to interfere with various TSH actions in human thyroid membranes (2, 7-9), this report adds strong evidence that asialo-hCG interacts directly with TSHr. Thus, asialo-hCG seems to be truly an antagonist of the hTSHr, because functionally it inhibited bTSH-stimulated adenylate cyclase activity, but was devoid of intrinsic activity in HTC-TSHr cells. Its mechanism of inhibition appears to be competitive in nature, as has been noted previously and demonstrated here again in its direct interaction with recombinant hTSHr $(2,7)$. Information on the interaction of desialylated hCG variants with hTSHr may be particularly relevant in the consideration of such substances as possible TSH receptor blockers in the study and treatment of Graves' disease. In this respect, asialo-hCG, owing to its short plasma half-life, would be available mainly for in vitro experiments, whereas other desialylated hCG variants, such as asialoagalacto-hCG, may be suitable for in vivo use as an experimental TSHr blocker (9).

\section{Acknowledgments}

We would like to acknowledge the expert technical assistance of Sabine Hoppe and Heike Sippel.

\section{References}

1. Amir SM, Sullivan RC, Ingbar SH. 1980 In vitro responses to crude and purified hCG in human thyroid membranes. J Clin Endocrinol Metab. 51:51-58.

2. Hoermann R, Amir SM, Ingbar SH. 1988 Evidence that partially desialylated variants of human chorionic gonadotropin (hCG) are the factors in crude $\mathrm{hCG}$ that inhibit the response to thyrotropin in human thyroid membranes. Endocrinology. 123:1535-1543.

3. Amir SM, Endo K, Osathanondt R, Ingbar SH. 1985 Divergent responses by human and mouse thyroids to human chorionic gonadotropin in vitro. Mol Cell Endocrinol. 39:31-37.

4. Davies TF, Platzer M. 1986 hCG-induced TSH receptor activation and growth acceleration in FRTL-5 thyroid cells. Endocrinology. 118:2149-2151

5. Hershman JM, Lee HY, Sugawara M, et al. 1988 Human chorionic gonadotropin stimulates iodide uptake, adenylate cyclase, and deoxyribonucleic acid synthesis in cultured rat thyroid cells. J Clin Endocrinol Metab. 67:74-79.

6. Hoermann R, Keutmann HT, Amir SM. 1991 Carbohydrate modifications transform human chorionic gonadotropin into a potent stimulator of adenosine $3^{\prime}, 5^{\prime}$-monophosphate and growth responses in FRTL-5 thyroid cells. Endocrinology. 128:1129-1135.

7. Carayon P, Amr S, Nisula BC. 1980 A competitive antagonist of thyrotropin: asialo-choriogonadotropin. Biochem Biophys Res Com mun. 97:69-74.

8. Amir SM, Sullivan RC, Ingbar SH. 1981 The effect of desialylation on the in vitro interaction of human chorionic gonadotropin with human thyroid plasma membranes. Endocrinology. 109:1203-1211.

9. Hoermann R, Schumm-Draeger PM, Rehbach K, Mann K. 1991 Asialoagalacto-human chorionic gonadotropin, a carbohydratemodified variant of human chorionic gonadotropin, antagonizes the stimulatory actions of bovine thyroid-stimulating hormone on thyroid function and HLA-DR expression in human thyroid in vitro and in vivo. I Clin Invest. 88:1947-1954.

10. Parmentier M, Libert F, Maenhaut C, et al. 1989 Molecular cloning of the thyrotropin receptor. Science. 246:1620-1622.

11. Nagayama Y, Kaufman KD, Seto P, Rapoport B. 1989 Molecular cloning, scquence and functional expression of the cDNA for the human thyrotropin receptor. Biochem Biophys Res Commun. 165:1184-1190.

12. Tomer Y, Huber GK, Davies TF. 1992 Human chorionic gonadotropin (hCG) interacts directly with recombinant human TSH receptors. J Clin Endocrinol Metab. 74:1477-1479.

13. Goretzki PE, Frilling A, Simon D, Rastegar M, Ohmann C. 1989 Growth regulation of human thyrocytes by thyrotropin, cyclic adenosine monophosphate, epidermal growth factor and insulin-like growth factor. In: Goretzki PE, Roeher HD, eds. Growth regulation of thyroid gland and thyroid tumors. Basel: Karger Verlag; vol 18, $56-80$

14. van Hall, Vaitukaitis JL, Ross GT, Hickman JW, Ashwell G. 1971 Immunological and biological activity of $\mathrm{hCG}$ following progressive desialylation. Endocrinology. 88:456-464.

15. Warren L. 1959 The thiobarbituratic acid assay of sialic acids. J Biol Chem. 234:1971-1975.

16. Felgner PL, Gadek TR, Holm M, et al. 1987 Lipofection: a highly efficient, lipid-mediated DNA-transfection procedure. Proc Natl Acad Sci USA. 84:7413-7417.

17. Derwahl M, Kuemmel M, Goretzki P, Schatz H, Broecker M. 1993 Expression of the human TSH receptor in a human carcinoma cell line that lacks an endogeneous TSH receptor: growth inhibition by cAMP. Biochem Biophys Res Commun. 191:1131-1138.

18. Derwahl M, Schatz H, Bolle B, Pohl A, Meyer K. 1992 Measurement of stimulating TSH receptor antibodies in sera of patients with Graves' disease by a recombinant TSH receptor bio-assay. Exp Clin Endocrinol. 100:75-79. 
19. Scatchard G. 1949 The attractions of proteins for small molecules and ions. Ann NY Acad Sci. 51:660-672.

20. Munson PJ, Rodbard D. 1980 Ligand: a versatile computerized approach for characterization of ligand-binding systems. Anal Biochem. 107:220-239.

21. Tisne L, Barzelatto J, Stevenson C. 1955 Estudio de function tiroidea durante el estado gravido-puerperal con el yodo radioactivo. Bol Soc Chil Obstet Ginecol. 20:246-251.

22. Cohen JD, Utiger RD. 1970 Metastatic choriocarcinoma associated with hyperthyroidism. J Clin Endocrinol Metab. 30:423-429.

23. Nisula BC, Ketelslegers JM. 1974 Thyroid-stimulating activity and chorionic gonadotropin in vitro. J Clin Invest. 54:494-499.

24. Kenimer JG, Hershman JM, Higgins HP. 1975 The thyrotropin in hydaditiform mole is human chorionic gonadotropin. J Clin Endocrinol Metab. 40:482-489.

25. Sowers JR, Hershman JM, Carlson HE, Pekary AE. 1978 Effect of human chorionic gonadotropin on thyroid function in euthyroid men. J Clin Endocrinol Metab. 47:898-901.

26. Carayon P, Lefort G, Nisula BC. 1980 Interaction of human chorionic gonadotropin and human luteinizing hormone with human thyroid membranes. Endocrinology. 106:1907-1916.

27. Pekonen F, Alfthan H, Stenman UH, Ylikorkala O. 1988 Human chorionic gonadotropin (hCG) and thyroid function in early human pregnancy: circadian variation and evidence for intrinsic thyrotropic activity of hCG. J Clin Endocrinol Metab. 66:853-856.

28. Glinoer D, de-Nayer P, Bourdoux P, et al. 1990 Regulation of maternal thyroid during pregnancy. J Clin Endocrinol Metab. 71:276-287.

29. Pekary AE, Jackson IMD, Goodwin TM, Pang XP, Hein MD, Hershman JD. 1993 Increased in vitro thyrotropic activity of partially sialated human chorionic gonadotropin extracted from hydatidiform moles of patients with hyperthyroidism. J Clin Endocrinol Metab. 76:70-74.

30. Nisula BC, Taliadouros GS, Carayon P. 1980 Primary and secondary biologic activities intrinsic to the human chorionic gonadotropin molecule. In: Segal S, ed. Chorionic gonadotropin. New York: Plenum Press; 17-35.

31. Amir SM. 1986 Human chorionic gonadotropin: a negligible human thyroid stimulator. In: Ingbar SH, Braverman LE, eds. Werner's the thyroid, 5th ed. Philadelphia: Lippincott; 1088-1097.
32. Hershman JM. 1991 Hyperthyroidism caused by trophoblastic tumors. In: Ingbar SH, Braverman LE, eds. Werner's the thyroid. A fundamental and clinical text, 6 th ed. Philadelphia: Lippincott; 705709.

33. Kennedy RL, Darne J. 1991 The role of hCG in regulation of the thyroid gland in normal and abnormal pregnancy. Obstet Gynecol. 78:298-307.

34. Hershman JM. 1992 Editorial: role of human chorionic gonadotropin as a thyroid stimulator. J Clin Endocrinol Metab. 74:258-259.

35. Mann K, Hoermann R. 1993 Thyroid stimulation by placental factors. J Endocrinol Invest. 16:378-384.

36. Chazenbalk GD, Nagayama Y, Kaufman KD, Rappport B. 1990 The functional expression of recombinant human thyrotropin receptors in nonthyroidal eukaryotic cells provides evidence that homologous desensitization to thyrotropin stimulation requires a cellspecific factor. Endocrinology. 127:1240-1244.

37. Lefort GP, Amr S, Carayon P, Nisula BC. 1984 Relevance of the low and high affinity thyrotropin binding sites of human thyroid membranes to the stimulation of adenylate cyclase. Endocrinology. 114:1005-1011.

38. Hoermann R, Amir SM, Nomura T, Ingbar SH. 1989 Design of a long-lived TSH antagonist from derivatives of human chorionic gonadotropin. Endocrinology. 124:223-232.

39. Yoshimura M, Hershman JM, Pang XP, Berg L, Pekary AE. 1993 Activation of the thyrotropin (TSH) receptur by human chorionic gonadotropin and luteinizing hormone in chinese hamster ovary cells expressing functional human TSH receptors. J Clin Endocrinol Metab. 77:1009-1013.

40. Zakarija M, McKenzie JM. 1978 Zoological specificity of human thyroid-stimulating antibody. J Clin Endocrinol Metab. 47:249-254.

41. Perret J, Ludgate M, Libert F, et al. 1990 Stable expression of the human TSH receptor in CHO cells and characterization of differentially expressing clones. Biochem Biophys Res Commun. 171:1044-1050.

42. Costagliola S, Swillens S, Niccoli P, Dumont JE, Vassart G, Ludgate M. 1992 Binding assay for thyrotropin receptor autoantibodies using recombinant receptor protein. J Clin Endocrinol Metab. 75:1540-1544.

43. Smith BR, McLachlan SM, Furmaniak J. 1988 Autoantibodies to the thyrotropin receptor. Endocr Rev. 9:106-121. 